\title{
Renewal of Ethnography in the Time of the COVID-19 Crisis
}

\author{
Dan Podjed \\ Research Centre of the Slovenian Academy of Sciences and Arts, Institute of \\ Slovenian Ethnology, Ljubljana, Slovenia \\ e-mail:dan.podjed@zrc-sazu.si
}

ABSTRACT During the COVID-19 pandemic, a crisis of anthropological research has occurred that requires both methodological and epistemological considerations. The basic tool of anthropology is field research based on participant observation in situ and in close contact with people. However, during the pandemic, it has become almost impossible to conduct research in this way, as distancing and self-isolation are required. During the crisis, anthropologists have mostly stayed at home and have had to find new approaches to studying ways of life, including the use of digital methods. This article presents examples of such remote and technology-enabled ethnographic research. It illustrates the theoretical premises with the results from various research projects that have used remote ethnography, and complements them with the author's reflections on anthropological work and daily life, written as an online blog during the COVID-19 pandemic, in which he outlined how he interacted with people via digital devices.

Key words: anthropological methods, remote ethnography, digital ethnography, armchair anthropology, COVID-19, crisis. 


\section{Introduction}

"The shopping experience was completely different from last week. Everything seemed somehow normal, but at the same time I felt that strange uncanny feeling that Freud called das Unheimliche. That feeling we get, for example, when we look at the coffin containing the body of a relative, which is on the one hand familiar, but also strange and unusual. The store was almost as crowded as has always been, except that the shoppers were behaving in a way that was unexpected. Almost half of us wore rubber gloves and a mask on our faces, and we moved like molecules of gas; we tried to stay as far apart from each other as possible. We didn't even look at each other, let alone started a conversation." This paragraph was written on $17^{\text {th }}$ March, 2020, as part of a longer recording about my everyday life that I shared in Slovenian and English language on Facebook, Twitter, Instagram, and LinkedIn. Since that experience, I kept recording on a daily basis what had been happening in our family and in society during the COVID-19 pandemic, which isolated people due to various restrictions and measures for preventing the spread of virus. In the autumn of the same year, a collection of recordings was published in a book titled Indoor Anthropology (in Slovenian Antropologija med stirimi stenami; Podjed 2020). The book summarises my impressions about the "first wave" of the virus spread in Slovenia and tried to present how the society had transformed due to the coronavirus disease, how our everyday habits had started to change, how the crisis had been gradually turned into a "new normal" (cf. Kurnosov and Varfolomeeva, 2020; Žikić, Stajić \& Pišev, 2020) and how it demarcated the beginning of the "Coronacene," i.e., a new epoch which could in opinion of some authors even replace the term "Anthropocene" (Higgins, Martin and Vesperi, 2020).

The initial record in the blog, which is now partly re-published in this introduction, was made when I first went to the store after the epidemic was officially declared in Slovenia and was surprised at how people began to behave differently during the crisis because of expectations for "social distancing," as the media and some governmental institutions called avoiding physical contact because of the risk of transmitting the virus infection. ${ }^{1}$ In the period when the recording was made, I was not only confronted with the transition to the "new normal," as the public has started to describe that liminal situation, and faced with the health crisis, i.e., the COVID-19 pandemic, which affected our everyday life and mundane routines, I also had to face the crisis of anthropological research, which would require an in-depth methodological and an epistemological reflection on the present state and the future of the discipline. I was - as many colleagues in Slovenia and abroad - stuck in "lockdown", without a possibility to directly interact with people. Being stuck at home meant that my fellow anthropologists and I were unable to rely on ethnography as the fundamental tool of anthropology, which is based on participant

$\mathbf{1}$ The term "social distancing" is misleading, as it symbolises the dissolution of communities and society in the time of crisis. "Physical distancing" or "viral distancing" would be therefore more adequate terms. 
observation in a specific location and in close contact with people. In 2020, this kind of "traditional" anthropological research in situ became almost impossible due to the demand for distancing and self-isolation. During the global health crisis, anthropologists, including myself, had to turn into a new kind of "armchair anthropologists" and were forced to find alternative possibilities to study the ways of life.

The COVID-19 crisis, of course, is not the only one that has and will change the discipline and its research methods. We can expect further methodological adaptations in the face of other anticipated crises, such as natural disasters, climate crises, social upheavals, and so on. In addition, in order to protect the environment and reduce greenhouse gas emissions produced by international travels, anthropologists will have to adapt the research methods and begin to use widely available technologies that enable new ways of doing research online and remotely. ${ }^{2}$ In this article I present some opportunities for the renewal of ethnography and its implementation in the time of the COVID-19 crisis and beyond. The presented methods and approaches, based primarily on digital technologies, can make ethnographic research cheaper, faster, more efficient, and more appropriate in terms of environmental protection - or they can at least be an important complement to ethnography in situ as it has been carried out from the time of Bronisław Malinowski and other prominent figures of the discipline in the early $20^{\text {th }}$ century.

The article presents examples of research projects where my colleagues and I utilised the remote and digital methods before the global health crisis. It compares the approaches and results to the experiences and recommendations of other ethnographers during the COVID-19 pandemic, such as the collectively produced online manual Doing Fieldwork in a Pandemic, published by Deborah Lupton (2020). The article tries to explain that ethnography makes sense in times of crisis - perhaps even more than in a state of "normality" - and provides information, solutions and inspiration for anthropologists who want to keep researching ways of life without physical presence or want to enhance and upgrade their existing method, i.e., ethnography in situ.

\section{Revival of armchair anthropology}

"Being there" became a fundamental premise of ethnographic fieldwork and a conditio sine qua non in the $20^{\text {th }}$ century anthropological research (Geertz, 1988; Watson, 1999; for an alternative viewpoint see Jarvie, 1967). Until very recently it was virtually impossible to imagine a serious anthropological endeavour without participant observation and without an in-depth interaction with people. The anthropological community therefore experienced a major shock during the COVID-19 pandemic.

2 Just as videoconferencing can reduce the researchers' carbon footprint by almost half (Achten, Almeida \& Muys 2013), remote ethnographic research can contribute to a more sustainable and environmentally friendly ethnography. 
The researchers had to stay indoors; they were unable to gain direct access to people and explore lifestyles of others to accomplish their work and mission.

However, during the pandemic, the notion of being immobilised, inactive and even useless in the role of "armchair anthropologists" was proven wrong for several reasons. First, the researchers were of course not completely passive and their time was spent in useful and innovative ways; often, the restrictions and limitations have proven to be actually a source of their innovativeness. The situation is somewhat, but not fully, comparable to the $19^{\text {th }}$ century armchair anthropology, which was not - as it is often imagined - a passive engagement from afar with minimal analytical reflection. In fact, researchers of that period were already seeking new approaches to gathering information and trying to improve their methods (Sera-Shriar, 2014). Similarly, anthropologists sought ways to reach people in times of crises, such as during the World War II. At that time, the prominent anthropologists such as Margaret Mead, Gregory Bateson, and Ruth Benedict had virtually no choice but to study the cultures of Japan, Germany, and other countries at war from a distance and through radio, film, novels, and poetry (Postill, 2016; Mead and Métraux, 2000). In the time of crisis, some of them even managed to write up influential and internationally acclaimed monographs, such as The Chrysanthemum and the Sword by Ruth Benedict (1967), without actually "being there". Second, the contemporary ethnographic method is not based only on the revolutionary approach of Bronisław Malinowski, Franz Boas and other "founding fathers" of anthropology (Eriksen and Nielsen, 2013), who began long-term fieldwork in foreign sociocultural environments in the late $19^{\text {th }}$ and early $20^{\text {th }}$ centuries (Jarvie, 1970), but also has its roots in national statistics at the time of the Enlightenment (Vermeulen, 2015) and in research in domestic settings (Muršič, 2011). Ethnography can, as it has been proven many times, also take place "at home" or "in proximity" and is not necessarily defined by the "exoticism" of its subject matter and by the cultural or geographic distance that separated the researcher from the researched group (Peirano, 1998). Third, in contemporary time, ethnographic research at a distance - and even from an actual armchair placed in a living room - is possible with the help of information and communications technologies that allow us to reach people using the so-called smart devices, e.g., smartphones, tablets and computers, that facilitate work and enable the understanding of cultural patterns in digital or physical spaces, or in a hybrid intertwining of both digital and physical realm (Przybylski, 2021).

Digital technologies have proven to be instrumental for anthropological research in the time of the pandemic and will be important also in the future for the renewal of the disciplinary method. Ethnography carried out by the use of Zoom, Skype, Teams, and other technology-enabled means of communication has highlighted the complexities of anthropological experience (Horton, 2020) and various aspects of proximity (Cesare Schotzko, 2020). The use of the technological solutions has redefined the possibilities of global coexistence in time - and not necessarily in space. Furthermore, 
it has been shown that remote communications can enable different forms of physical, sensory and emotional responses even with simple forms of communication, such as Zoom (Howlett, 2021), and even more so with tactile accessories and devices for accessing the so-called virtual reality that make people feel like they are together even though they are physically separated (Bennett, 2020). Due to the ubiquitous and widely available technologies (Dourish \& Bell, 2011), the geographically limited but digitally supported research has become a prerequisite for the implementation of ethnography during the pandemic. It has sped up the "digital transformation" in society and simultaneously supported the use of remote and digitally enabled ethnographic methods. As it is explained by Marnie Howlett (2021), the COVID-19 pandemic has forced us to rapidly rethink our approaches to research and inspired new questions around conducting transparent, reflexive, and ethical research. "These considerations will prove imperative for the ways we understand 'fieldwork' within a post-pandemic world," says Howlett in the conclusion of her article (2021:13).

As we can see from historical and recent examples presented in this section, doing remote ethnographic research is nothing groundbreakingly new. Remote research in social science and humanities research, including anthropology, has actually been conducted remotely and online for many decades - lately also by the means of new technologies. Interviews, for example, have long been conducted by anthropologists via phone, Zoom, or Skype (Janghorban, Roudsari and Taghipour, 2014), as have been by now well established "netnography" as a set of online research practices rooted in participant observation (Kozinets 2020), and other types of research in digital spaces and online social networks (e.g., Boellstorff, 2008; Boellstorff et al., 2012; Miller, 2011; Miller et al., 2016; Podjed, 2010). ${ }^{3}$ However, the COVID-19 pandemic has proven to be an opportunity to show that the remote ethnography is not necessarily an "appendix" of anthropological methods. In fact, it can in some circumstances become its fundamental approach, especially when dealing with crises and, as we will see in the following sections, when anthropologists are involved in interdisciplinary research and development $(\mathrm{R} \& \mathrm{D})$ projects which often include physically remote demonstration sites.

3 In fact, we should start dividing these kinds of remote ethnography, with or by digital means, in two parallel and sometimes intersecting streams. The first is the digital ethnography, which means ethnography carried out by digital technologies, such as computers and various software solutions. The other is the ethnography of the digital, which describes ethnography carried out in digital, virtual or online space. In this article, I focus more on the former, i.e., the use of digital methods to remotely study ways of life and use the label remote ethnography to present the digitally supported research. 


\section{Examples of remote ethnography before and during the pandemic}

Before the COVID-19 pandemic struck the world in 2020 and influenced the ethnographic research methods, we already tried out the remote ethnography approaches in several R\&D projects, of which this article highlights three; one was funded by the Slovenian Research Agency and two by the EU Horizon 2020 programme. The analyses are compared and supplemented with other research methods and findings gained during the COVID-19 pandemic, including writing the Indoor Anthropology blog.

\subsection{DriveGreen}

The two initial questions that the DriveGreen project lasting from 2014 to 2017 sought to answer were how people behave in traffic and how we can influence their driving habits and promote environmentally sustainable mobility. In the research, we assumed that driving is not only an individual habit, but also a social practice. As it has proven in our research, drivers often imitate each other, learn formal and informal rules, adapt to the situation on the road and communicate with each other, creating a set of habits, which we named the driving habitus (Bourdieu, 1990; Kuipers, 2012; Podjed and Babič, 2015). In our multi-sited study, we first tried to identify the foundations on which the driving habitus is formed in different cities. From July 2014 to September 2015 we conducted ethnographic research in Ljubljana, from September to December 2015 in Belgrade, from January to March 2016 in Budapest and from April to July 2016 in Durham and Newcastle. Ethnography had proven to be a particularly relevant method for studying traffic and driving because each place where we conducted a study differs in terms of promoting sustainable mobility, due to specific habits and practices related to cultural factors as well as economic, political and geographical characteristics, climate conditions, infrastructure, etc. All these factors could not be entirely captured and experienced in other way than by doing the qualitative research in situ, i.e., talking to people, observing their behaviour on the road, using the public transport and becoming fully immersed in traffic in other engaged ways.

Throughout the DriveGreen project the qualitative (ethnographic) research was supported by quantitative approaches, i.e., remote measurements of driving style with telematics devices and other technological solutions, such as digital cameras and heart rate monitors, to analyse drivers' body parametres (Burger et al., 2017). We relied on the vehicle tracking telematics solutions to study how driving styles differ in different locations and situations and how people adapt to traffic in unfamiliar settings. By high-resolution cameras installed in the vehicles, we filmed what was happening outside the driver's field of view and the relationships between road users, such as cyclists, pedestrians, and drivers. We also used heart rate monitors to measure how a person experiences traffic in their own vehicle and which situations are most stressful for them. In the studies, we tried to find the right balance between qualitative and 
quantitative approaches and show how they can be intertwined into a mixed method approach (see, e.g., Brannen, 2005; Cresswell and Plano Clark, 2011; Morgan, 2014; Morse and Niehaus, 2009; Teddlie and Tashakkori, 2009). The combined method, which for the purposes of the study was called the "augmented ethnography" (Podjed, 2017), proved effective and useful as we used devices and sensors to enhance the researchers' capabilities and senses by sensors and other devices built in vehicles and thus gather additional information about where and how people drive. However, the key questions about why people drive the way they do were primarily obtained through interviews, focus groups, participant observation, and other qualitative approaches and techniques. Thus, we kept checking the data obtained from the measurements with the questions we asked people, and at the same time we continuously checked the information people gave us with the measurements by different technological tools. With this kind of "circular" research design (cf. Pretnar and Podjed, 2018), we tried to make a connection between quantitative and qualitative findings.

An important outcome of the project was the realization that engineers and anthropologists can successfully and equally participate in the development of research methods, and that ethnography as a basic anthropological method is not necessarily an appendage of interdisciplinary research and development processes, but can actually play an instrumental role in it. In addition to all of the technologies used to study driving and traffic, we retained and even emphasised "traditional" ethnographic approaches, from interviews to participant observation, and combined them into an approach in which researchers simultaneously collected, analysed, and intertwined qualitative and quantitative data and insights about the behaviour of people on the road.

In the DriveGreen project we had many good examples of interdisciplinary collaboration and sharing of methodology, knowledge, and practices. However, we also noticed several methodological obstacles that affected our fieldwork and the interpretation of results. A relevant and persistent issue was how to make the engineers in the research team aware of the value of ethnography and qualitative approaches on the one hand, and how to make the ethnographers understand and accept the relevance of digital solutions, tracking devices, cameras, heart rate monitoring belts, and other technologies on the other hand. We did not fully solve this problem throughout the project. However, mutual collaboration among researchers has brought about significant change on both sides - the social sciences and humanities side and the engineering side. The change was mainly influenced by the establishment of a common terminology throughout the project across qualitative and quantitative methods, approaches, and tools.

Another challenge of the joint research was related to the interpretation of the results collected by different methods, which had to be done in two ways. The team had to produce scientific outputs, such as conference proceedings, articles, and book chap- 
ters. At the same time, the researchers had to "translate" the findings from the field into relevant development recommendations, since the research on driving habits was carried out to inform the developers of the smartphone application for promoting sustainable mobility. This phase proved particularly difficult for the anthropologists and other social scientists involved, as we had to make a shift from descriptive to prescriptive interpretation of the findings. Instead of just describing how people move around the cities studied, we had to help draw a development plan, draw sketches (the so-called "wireframes") of the smartphone application for supporting sustainable mobility (for details about the app development see Podjed 2019), and keep an eye on the ethnographic findings from the field and the people involved in the study. The obstacles in the methodology and interpretation of the results were overcome by the "learning by doing" approach: the social scientists and engineers analysed their findings together and jointly created the development plan, which was enhanced by constant feedback from the developers.

In three years of the DriveGreen project we managed to establish a common interdisciplinary vocabulary which enabled a practical test of remote research methods. The anthropological part of the research team thus learned the meaning of previously unknown abbreviations and became familiar with the creation of wireframes that were prepared for the development of a smartphone application to promote sustainable mobility. At the same time, the engineering part of the project team learned how to prepare and conduct interviews and focus groups and why participant observation can be useful in understanding driving habits. Perhaps most importantly, we developed a common methodology which was later extended to several other R\&D projects. In all of them, sensors and other technological devices which enhanced ethnographic research became relevant to understand habits, practices and routines. In this sense, the DriveGreen project highlighted possibilities for "extending and upgrading the existing ethnographic approaches, which have often put anthropologists and other social scientists in an ambiguous position of simultaneously being researchers and the main research instruments - all in one person" (Podjed, 2017:16).

\subsection{MobiStyle}

A more comprehensive test of the remote ethnography was carried out in the MobiStyle project (2016-2020, EU Horizon 2020 programme). The aim of this project was to raise awareness and motivate building-users to change their habits and practices by developing new services to remotely monitor energy consumption and indoor climate, and to promote healthy lifestyles and well-being. In the project we tried to make a shift from buildings and technologies to people and their habits connected to energy consumption. We wanted to find out how people use buildings and devices, both at home and at work or while studying. We were interested in how people consume energy and how we can change their lifestyle and influence the formation of sustainable habits in the long term, using different technologies and non-technological means. 
In this project, ethnographic approaches allowed the interdisciplinary team to gain a deeper understanding of human behaviour and moved beyond the Big Data collected through technological solutions. In addition, the ethnographic research provided insights into Thick Data, i.e., a context for more complex interpretations of social interactions, human feelings, choices, and experiences (see, e.g., Wang, 2013; Pretnar and Podjed, 2018, 2021b). For example, we used ethnographic methods to supplement measurements by sensors and other devices and evaluate the success of an energy saving campaign in five demonstration cases: a neighbourhood in Denmark, a smart city in Poland, a smart university building in Slovenia, a hotel in Italy, and an office building in the Netherlands. The findings from the initial ethnographic research were synthesized into recommendations for developers, which were adapted in collaboration with engineers and other experts and tailored to different scenarios, characteristics of buildings, and the people living in them (Tisov et al., 2017; Podjed, 2019).

The main problem for ethnography carried out in the MobiStyle project was a small team of anthropologists and other social scientists who were unable to simultaneously carry out interviews, focus groups, participant observation, and other approaches to study ways of life in five remote demonstration cases. Therefore, we had to change our strategy; instead of the in-depth and extended research in situ, we relied on remote conversations with people via software tools. We first organised a focus group with the people in Slovenia who were physically accessible. Afterward, we carried out online focus groups on Skype in four other locations, which were moderated by local team members who were most often engineers. However, the ethnographers were always "virtually" present at the discussions via online telecommunication tools; in this way, we tried to interact with people and raise additional questions to obtain more information about the built environment.

The approach proved to be successful, since we were able to carry out the initial part of the research quickly and efficiently. We were of course aware it was not a "real" ethnography which is based on long-lasting interactions with people and immersion in the site and local society. Therefore, we tried to avoid using the term "ethnography" in MobiStyle and other similar projects, including Infinite presented in the next section. We decided to start using instead the term "ethnography inspired research" (Cerinšek et at., 2021) which can also be carried out by engineers and other experts to supplement their R\&D activities.

\subsection{Infinite}

The main objective of the Infinite project (lasting from 2020 to 2025, EU Horizon 2020 programme), is to increase the market share of building retrofit kits that are robust, accepted by stakeholders, and based on a sustainable life cycle, thus contributing to the decarbonisation of buildings in the EU. In this international project which 
started in the second half of 2020, we were once more faced with difficulties to carry out the ethnographic research in demonstration sites, located in different countries. This time, the main reason was the COVID-19 pandemic which prevented the research team to visit the sites and carry out the qualitative research in situ as it was planned in the project proposal. Once more we had to rely on remote ethnography and start carrying out interviews and focus groups online. The online communication tools, such as Zoom and Teams, enabled us to get a rapid overview of the situation and allowed the researchers to collect information about the needs and expectations of occupants, building managers, technology developers, and other stakeholders in different locations. However, the collected information was often not tactile and comprehensive enough; we were not able to get a deeper insight into the lives and routines of people with only remote approaches. Therefore, we decided to combine online and offline, i.e., remote and "traditional", ethnography to get a better overview of the situation. In the Infinite project the "hybrid" approach has proven to be especially relevant for establishing the initial face-to-face interaction with locals and to establish a good rapport with building occupants and other stakeholders, which enabled further investigations with the help of online communication tools.

The main advantage of online research in the Infinite project was that the people involved in the research were already used to online conversations due to their experiences during the pandemic. In a sense, it was easier to "break the ice" by remote conversations and by keeping contacts online, as physical distancing was required at the time of our initial research. In January 2021, for example, it was inconceivable for a Slovenian to visit communities in Italy and have casual, face-to-face conversations with them. Even more so, they could not be expected to conduct any kind of extended and in-depth participant observation in situ, especially not in the studied buildings.

Such preliminary experiences in the Infinite project show that the research requirements of large-scale international projects have already been adapted to the "new normal" in the EU and beyond. The action plan proposed in the so-called Description of Action (often abbreviated to DoA) can - and even should - be adapted to allow ethnography to be conducted remotely and at a distance. In the future, we can probably expect that the DoA documents of international project proposals will involve these kinds of ethnographic research - in order to carry out the research in similar crises that might occur in the future.

\subsection{Other experiences during the COVID-19 pandemic}

I will now shift the attention from international $\mathrm{R} \& \mathrm{D}$ projects and conclude this section with the Indoor Anthropology blog, which has turned into a book with the same name. The records in the blog were, as explained in the beginning of this article, published online on a daily basis during the "first wave" of the COVID-19 pandemic in Slovenia and elsewhere, and started to attract public attention in media and general 
public. The blog has thus gradually evolved into a dialogue between the author and society. Because of the audience on the internet who expected a new report on a daily basis, I began to move from a single page to longer posts which were often commented online and I tried to reply to these comments. It turned out that these very comments, which were later also published in the book at the end of each chapter - anonymously, of course - were an important part of the new method we call remote ethnography. The online conversation between the self-proclaimed "armchair anthropologist" with no real research plan reflected well the social situation in the country and beyond its borders during the first wave of the epidemic and contained various observations that would remain hidden without the equal relationship established during online debates. In this case, for example, I switched from an anthropologist as an observer to a "narrator" who revealed his life and in this way encouraged others to show their own mundane activities.

As was said before, some posts went rather unnoticed, while others sparked heated debates, such as when I described and showed in an attached photo (Figure 1) how our family members shower and disinfect all the packaged food we bring home in the bathroom. "But showering everything you buy is a bit extreme in my opinion," someone commented on Facebook. "We just follow the advice of experts: unwrap what's packed, disinfect what's possible," I replied to this person (Podjed, 2020:88). An avalanche of comments then erupted, with some admitting that they also tried to disinfect the goods themselves in a similar way, while others tried to convince me to refrain from such "nonsensical" approaches.

Figure 1.

In the Indoor Anthropology blog the author of this article presented what was going on in his daily life during the pandemic. Ljubljana, Slovenia, 6th April, 2020.

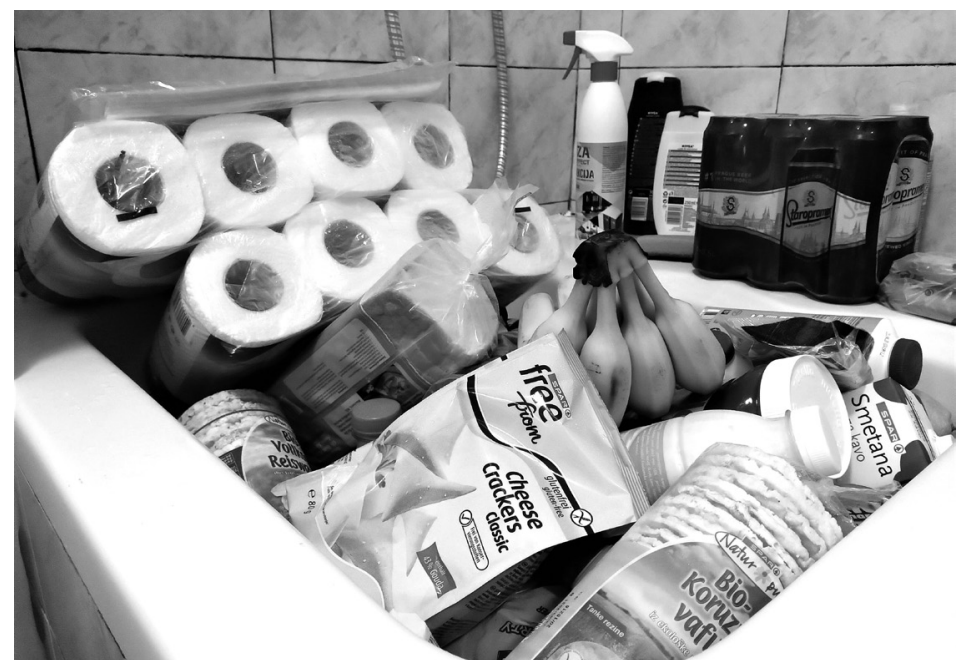

(Courtesy: Dan Podjed.) 
Exactly these kinds of random and serendipitous experiences during the COVID-19 pandemic had proven to be important in renewing ethnography and introducing new approaches that can help research in times of crisis and enhance existing approaches to the analysis of routines, habits, and practices. The situation of "not being there" was perhaps even more intriguing for readers of the blog who started to reveal their daily lives and open new topics through a more unplanned and unstructured communication with the anthropologist. The experience with writing the blog also showed how the online social networks, which have started to connect people stuck in "lockdown" in new and unexpected ways, should be taken much more seriously in understanding our lives, practices, and routines, especially in times when we spend a large part of our life at home and in front of screens.

\section{Discussion}

The examples of various projects and research findings before and during the COVID-19 pandemic show that the renewal of ethnography is necessary if we want to establish anthropological research at a distance and in times of normalcy and crisis. Technology plays, as the article tried to highlight in the examples above, an increasingly important role in supporting fieldwork in situ, enhancing established contemporary approaches, e.g., sensory ethnography (Pink, 2015), enabling the observation of people's behaviour at a distance using sensors and other devices (Pretnar and Podjed, 2021a, 2021b), and ensuring the conduct of interviews and focus groups using virtual conferencing tools. However, we cannot rely solely on technologies to save anthropology and its method in times of crises and beyond. As Góralska (2020:50) says, digital ethnography is not a "universal glue" with which we can fix all the changes that the COVID-19 pandemic and other crises bring to ethnographic practice. Nevertheless, it can help us further explore global structures, cultural practices and social phenomena if and when "armchair anthropology" remains the only option for researching and accessing people. However, in most cases the digital and remote ethnography should be supplemented by ethnography in situ, which assures another quality of interaction with locals, provides a different sensory experience of "being there", and helps establish a long-term rapport with people.

What are the next possible steps in the development of the method? On the basis of theoretical and practical findings presented in the article, I propose three approaches to solidify the remote ethnography as a meaningful and robust method which can be used in crises and beyond. The first is the acceleration of ethnography which is often perceived as slow-paced research and is thus not adapted for requirements of contemporary world, especially in interdisciplinary research and development projects which demand quick and efficient execution of tasks. The second approach is further intertwining of Big Data and Thick Data analysis. Instead of dividing studies of social realities into two separate streams, we can use both approaches simultaneously, 
without making a strict delineation between the qualitative and quantitative studies. The third approach is connected to the permanent use of information and communications technologies in solidifying the hybrid research approaches and getting rid of the unproductive division between ethnographic research in "virtual" or "digital" and "actual" or "physical" places (cf. Boellstorff, 2008). Since we spend more and more time online by using smart devices, such as phones, tablets and wearables, the distinction between the two realities has become blurred - even more so during the COVID-19 pandemic when we had to start working, teaching/learning, and researching remotely. The concept of "being there" should thus be understood in a different sense, perhaps by being present in time instead of in space - or being present in the same event instead of being present in the same place. The "event" could thus gradually become as - and often even more - relevant unit of ethnographic research as the "site" (see Ahlin and Li, 2019).

\section{Conclusion}

This article has presented examples of remote ethnography and technology-supported ethnographic research that can be carried out in times of "normality" as well as in times of crisis. As it tried to highlight, digital technologies can be helpful in understanding life in remote places that are inaccessible, or in places where it is difficult or forbidden to make direct contact with locals. However, anthropologists should not be overwhelmed by the idea of conducting ethnography only from a distance, without direct contact. After all, physical interaction with people provides additional information and enriches the otherwise "thin" description. The situation in the anthropological research is thus similar to other activities we have tested during the COVID-19 pandemic. For example, many of us tried socialising online, via Zoom or Skype, and talking to people on the other side of the screen. A common finding was that it is a good substitute, but it is not the same as physical meetings with colleagues and friends. Similarly, ethnography can be carried out online, using communication devices, software tools, and sensors. However, the sensory experience of interacting with people is limited and the thickness of ethnographic research can be diluted if the researchers are limited only to information gathered by online tools and through digital devices.

There will, of course, be new attempts to enrich and "thicken" the findings of remote ethnography through the use of augmented virtual reality tools, e.g., headsets and data gloves. Future devices, it is expected, will include simulation of touch, taste, and smell, as well as sensations such as hot or cold. Some experts predict that by 2030 we will be able to enter digital environments that seem completely real to all five of our senses simultaneously (Marr, 2020). So, at least in the near future, the experience of "being there" will remain the cornerstone of ethnographic research. However, anthropologists should not pretend that their main method does not need renewal and 
upgrading. The development of new possibilities offered by technologies should be closely followed to ensure a robust method in crises that can be expected in the future.

Of course, it is also important to anthropologically analyse the current situation during and after the COVID-19 pandemic, which marks an important "liminal state" in society when strangeness has not yet become the "new normal." I have also tried to depict the situation in the blog and book Indoor Anthropology, which I finished writing in May 2020, at the end of the "first wave," with the following words: "[T]he outside world is opening up again, and the strangeness of quarantine has disappeared. On the fifth day since the measures were announced, when I began writing these notes, I still wondered about the masked people walking through the store, but today the opposite is true: masked people are the new normal. / ... / We have internalised habits that seemed extremely foreign to us. What was unheard of five weeks ago suddenly seems necessary - from greeting people at a distance to shunning your own relatives and friends." Such ground-breaking situations which will have long-lasting influence on our ways of life should definitely be analysed using ethnographic approaches, either up close or from a distance.

\section{References}

1. Achten, W.; Almeida, J. and Muys, B. (2013). Carbon Footprint of Science: More Than Flying. Ecological Indicators, 34: 352-355.

2. Ahlin, T. and Li, F. (2019). From Field Sites to Field Events: Creating the Field with Information and Communication Technologies (ICTs). Medicine Anthropology Theory, 6 (2): 1-24.

3. Benedict, R. (1967 [1946]). The Chrysanthemum and the Sword: Patterns of Japanese Culture. London: Routledge \& Kegan Paul.

4. Bennett, N. (2020). Telematic Connections: Sensing, Feeling, Being in Space Together. International Journal of Performance Arts and Digital Media, 16 (3): 245-268.

5. Boellstorff, T. (2008). Coming of Age in Second Life: An Anthropologist Explores the Virtually Human. Princeton: Princeton University Press.

6. Boellstorff, T.; Nardi, B.; Pearce, C. and Taylor, T. L. (2012). Ethnography and Virtual Worlds: A Handbook of Method. Princeton and Oxford: Princeton University Press.

7. Bourdieu, P. (1990 [1976]). The Logic of Practice. Stanford: Stanford University Press.

8. Burger, G.; Syosoev, M.; Stojmenova Duh, E.; Pogačnik, M. and Guna, J. (2017). Methodology Recommendations for Subjective and Objective Assessment of Driving Styles, in: Podjed, D. and Bezjak, S. (Eds.). Research on the Road: Methodology and Practice of Studying Traffic, Driving Habits, and Sustainable Mobility. Ljubljana: ZRC Publishing, 81-109. 
9. Brannen, J. (2005). Mixing Methods: The Entry of Qualitative and Quantitative Approaches into the Research Process. International Journal of Social Research Methodology, 8 (3): 173-184.

10. Cerinšek, G.; Podjed, D.; Arko, S.; Bančič, D.; Vetršek, J. (2021 [in review]). New Horizons for Applied Ethnography: Ethnography-Inspired Research at the Core of Energy Efficiency Horizon 2020 R\&D Projects, in: New Business Models 2021: Conference Proceedings.

11. Cesare Schotzko, T. (2020). A Year (in Five Months) of Living Dangerously: Hidden Intimacies in Zoom Exigencies. International Journal of Performance Arts and Digital Media, 16 (3): 269-289.

12. Cresswell, J. and Plano Clark, V. (2011). Designing and Conducting Mixed Methods Research. Los Angeles: Sage.

13. Dourish, P. and Bell, G. (2011). Divining a Digital Future: Mess and Mythology in Ubiquitous Computing. Cambridge and London: The MIT Press.

14. Eriksen, T. H. \& Nielsen, F. S. (2013 [2001]). A History of Anthropology (2 ${ }^{\text {nd }}$ edition). London: Pluto.

15. Geertz, C. (1973). The Interpretation of Cultures: Selected Essays. New York: Basic Books.

16. Góralska, M. (2020). Anthropology from Home: Advice on Digital Ethnography for the Pandemic Times. Anthropology in Action, 27 (1): 46-52.

17. Higgins, R.; Martin, E. and Vesperi, M. (2020). An Anthropology of the COVID-19 Pandemic. Anthropology Now, 12 (1): 2-6.

18. Horton, Z. (2020). Viral Zoom: COVID-19 as Multi-Scalar Immune Failure. International Journal of Performance Arts and Digital Media, 16 (3): 319-340.

19. Howlett, M. (2021). Looking at the 'Field' through a Zoom Lens: Methodological Reflections on Conducting Online Research during a Global Pandemic. Qualitative Research. (https://journals.sagepub.com/doi/pdf/10.1177/1468794120985691). (Accessed on $15^{\text {th }}$ January 2021)

20. Janghorban, R.; Roudsari, R. L. and Taghipour, A. (2014). Skype Interviewing: The New Generation of Online Synchronous Interview in Qualitative Research. International Journal of Qualitative Studies on Health and Well-being, 9 (1): 24152.

21. Jarvie, I. (1967). On Theories of Fieldwork and the Scientific Character of Social Anthropology. Philosophy of Science, 34 (3): 223-242.

22. Jarvie, I. (1970 [1964]). The Revolution in Anthropology. London: Routledge \& Kegan Paul.

23. Kozinets, R. (2020 [2010]). Netnography: The Essential Guide to Qualitative Social Media Research ( $3^{\text {rd }}$ edition). London etc.: Sage.

24. Kuipers, G. (2012). The Rise and Decline of National Habitus: Dutch Cycling Culture and the Shaping of National Similarity. European Journal of Social Theory, 16 (1): 17-35.

25. Kurnosov, D. and Varfolomeeva, A. (2020). Constructing the Not-So-New Normal: Ambiguity and Familiarity in Governmental Regulations of Intimacies during the Pandemic. Anthropology in Action, 27 (2): 28-32. 
26. Lupton, D. (2020). Doing Fieldwork in a Pandemic. https://docs.google.com/ document/d/1clGjGABB2h2qbduTgfqribHmog9B6P0NvMgVuiHZCl8/edit. (Accessed on $6^{\text {th }}$ January 2021)

27. Marr, B. (2020). The Future of Virtual Reality. Forbes. https://www.forbes.com/ sites/bernardmarr/2020/12/18/the-future-of-virtual-reality-vr/. (Accessed on $16^{\text {th }}$ February 2021)

28. Mead, M. and Métraux, R. (2000 [1953]). The Study of Culture at a Distance. New York: Berghahn Books.

29. Miller, D. 2011. Tales from Facebook. London: Polity Press.

30. Miller, D.; Costa, E.; Haynes, N.; McDonald, T.; Nicolescu, R.; Sinanan, J.; Spyer, J.; Venkatraman, S.; Wang, X. (2016). How the World Changed Social Media. London: UCL Press.

31. Morgan, D. (2014). Integrating Qualitative and Quantitative Methods: A Pragmatic Approach. Los Angeles: Sage.

32. Morse, J. and Niehaus, L. (2009). Mixed Methods Design: Principles and Procedures. Walnut Creek: Left Coast Press.

33. Muršič, R. (2011). Metodologija preučevanja načinov življenja: Temelji raziskovalnega dela $v$ etnologiji ter socialni in kulturni antropologiji [The Methodology of Studying Ways of Life: The Foundations of Research in Ethnology and Social and Cultural Anthropology]. Ljubljana: University of Ljubljana, Faculty of Arts Publishing House.

34. Peirano, M. (1998). When Anthropology is at Home: The Different Contexts of a Single Discipline. Annual Review of Anthropology, 27: 105-128.

35. Pink, S. (2015). Doing Sensory Ethnography ( $2^{\text {nd }}$ edition). Los Angeles etc.: Sage.

36. Podjed, D. (2010). Omreženi prostori: Facebook kot znanilec vzpona omrežij in zatona prostorske paradigme. [Networked Spaces: Facebook as the Herald of the Rise of Networks and Decline of the Spatial Paradigm], in: Mencej, M. and Podjed, D. (Eds.). Ustvarjanje prostorov. Ljubljana: University of Ljubljana, Faculty of Arts Publishing House.

37. Podjed, D. (2017). Augmented Ethnography on the Road, in: Podjed, D. and Bezjak, S. (Eds.). Research on the Road: Methodology and Practice of Studying Traffic, Driving Habits, and Sustainable Mobility. Ljubljana: ZRC Publishing House, $15-41$.

38. Podjed, D. (2019). Razvoj etnografsko utemeljene tehnološke rešitve. [Development of an Ethnography-Based Technological Solution.] Glasnik Slovenskega etnološkega društva, 59 (1): 39-48.

39. Podjed, D. (2020). Antropologija med stirimi stenami: Spoznavanje družbe in sebe med pandemijo [Indoor Anthropology: Investigating Society and the Self during the Pandemic]. Ljubljana: ZRC Publishing.

40. Podjed, D. and Babič, S. (2015). Crossroads of Anger: Tensions and Conflicts in Traffic. Ethnologia Europaea, 45 (2): 17-33.

41. Postill, J. (2016). Remote Ethnography: Studying Culture from Afar, in: Hjorth, L.; Horst, H.; Galloway, A. and Bell, G. (Eds.). The Routledge Companion to Digital Ethnography. New York: Routledge, 61-69. 
42. Pretnar, A. and Podjed, D. (2018). Data Mining Workspace Sensors: A New Approach to Anthropology. Contributions to Contemporary History, 59 (1): 179-197.

43. Pretnar, A. and Podjed, D. (2021a [in review]). Making Sense of Sensors, in: Lanzeni, D. and Pink, S. (Eds.). Anthropology of Futures and Technologies. Abingdon and New York: Routledge.

44. Pretnar, A. and Podjed, D. (2021b [in review]). Ethnography Beyond Thick Data. Big Data \& Society.

45. Przybylski, L. (2021). Hybrid Ethnography: Online, Offline, and In Between. Los Angeles etc.: Sage.

46. Sera-Shriar, E. (2014). What Is Armchair Anthropology? Observational Practices in $19^{\text {th }}$-century British Human Sciences. History of the Human Sciences, 27 (2): 26-40.

47. Teddlie, C. and Tashakkori, A. (2009). Foundations of Mixed Methods Research: Integrating Quantitative and Qualitative Approaches in the Social and Behavioral Sciences. Thousand Oaks: Sage.

48. Tisov, A.; Podjed, D.; D’Oca, S.; Vetršek, J.; Willems, E.; Op’t Veld, P. (2017). People-Centred Approach for ICT Tools Supporting Energy Efficient and Healthy Behaviour in Buildings, in: Lennard, Z. (Ed.). Proceedings of the $5^{\text {th }} \mathrm{An-}$ nual Sustainable Places International Conference 7. Middlesbrough: MDPI, 675. https://www.mdpi.com/2504-3900/1/7/675.

49. Vermeulen, H. (2015). Before Boas: The Genesis of Ethnography and Ethnology in the German Enlightenment. Lincoln and London: University of Nebraska Press.

50. Wang, T. (2013). Why Big Data Needs Thick Data. Ethnography Matters, 13. http://ethnographymatters.net/blog/2013/05/13/big-data-needs-thick-data/. (Accessed on $3^{\text {rd }}$ January 2021)

51. Watson, C. (1999). Being There: Fieldwork in Anthropology. London and Sterling: Pluto Press.

52. Žikić, B.; Stajić, M. and Pišev, M. (2020). Нова друштвена и културна нормалност и ковид-19 у Србији од фебруара до маја 2020. Године [The New Normal and COVID-19 in Serbia from February to May 2020]. Issues in Ethnology and Anthropology, 15 (4): 949-978.

\section{Acknowledgements}

The research reported in this paper was part of the MobiStyle and Infinite projects that have received funding from the EU Horizon 2020 research and innovation programme. The work was also financed by the projects DriveGreen: Development of an Ecodriving Application for a Transition to a Low-Carbon Society (L7-6858) and Invisible Life of Waste: Development of an Ethnography-Based Solution for Waste Management in Households (L6-9364), and the core research programme Cultural Spaces and Practices: Ethnology and Folklore Studies (P6-0088). These projects and the programme were financially supported by the Slovenian Research Agency. 


\title{
Obnavljanje etnografije u doba krize COVID-19
}

\author{
Dan Podjed \\ Istraživački centar Slovenske akademije znanosti i umjetnosti, Institut za slovensku etnologiju, \\ Ljubljana, Slovenija \\ e-mail:dan.podjed@zrc-sazu.si
}

\section{Sažetak}

Tijekom pandemije COVID-19 dogodila se paralelno i kriza antropoloških istraživanja koja je zahtijevala metodološka i epistemološka razmatranja. Osnovni alat antropologije je terensko istraživanje temeljeno na promatranju sudionika in situ te bliski kontakt s ljudima. Međutim, tijekom pandemije postalo je gotovo nemoguće provesti istraživanje na ovaj način, jer su socijalno distanciranje i samoizolacija postali pravila ponašanja. Tijekom krize antropolozi su uglavnom ostajali kod kuće i morali su kreirati nove istraživačke pristupe proučavanju svakodnevnog života, uključujući i upotrebu digitalnih metoda. Ovaj članak predstavlja primjere takvih daljinskih i tehnološki omogućenih etnografskih istraživanja. Ilustrira teorijske postavke prikazujući rezultate različitih istraživačkih projekata koji su koristili daljinsku etnografiju te ih nadopunjuje autorovim razmišljanjima o antropološkom radu i svakodnevnom životu. Naime, autor je vodio dnevnik pisan kao mrežni blog tijekom pandemije COVID-19, u kojem je izložio komunikaciju putem digitalnih uređaja.

Ključne riječi: antropološke metode, daljinska etnografija, digitalna etnografija, fotelja antropologija, COVID-19, kriza. 